\title{
Kategese en Eksistensieteologie
}

\section{J DU P BEUKES}

Die huidige teologiese diskussie draai in 'n groot mate rondom die vraag na die betekenis van die Bybel vir die moderne mens. Die mens is op soek na 'n eietydse verstaan van die Bybel. Die Christendom van die verlede met sy sterk binding aan konfessie en kerk is net nie sondermeer aanvaarbaar vir die moderne mens nie. Hierdie mens is nie meer bereid om sonder deeglike motifering hom te buig voor instellings en bepalings uit die verlede nie. Hierdie situasie lei enersyds tot verwarring en andersyds tot 'n interne soeke na die sin van alles wat bestaan en behoort te bestaan. Vasgevang deur moderne tegnologiese ontwikkeling, ekonomiese onstabiliteit, sedeloosheid en normloosheid, het die lewe vir baie mense geword tot 'n sinlose spel wat op pad is na nêrens nie. Vroeër was die lewe vir die mens sinvol vanweë die feit dat bepaalde waarhede die bestaande vir hom as mens gemaak het tot sinvol. Die Griek met sy Neo-Platoniese denke het alles in die wêreld sondermeer as sinvol aanvaar. Vir die vroeë Christene was alles sinvol omdat hulle sonder nadere beredenering aanvaar het dat alles uit God, deur God en tot God is. Die middeleeuse gelowige kon vanweë sy teologie van natuur en bo-natuur vir alles 'n sinvolle plek gee. Die onwrikbare geloof in God se genade het vir die reformatore alles in die wêreld sinvol gemaak. In hierdie lang geskiedenis was die mens altyd op soek na iets wat alles in die wêreld vir hom sinvol gemaak het. Dit was gewoonlik 'n mag buite die mens en sy eie leefwêreld wat alles in die wêreld vir hom gemaak het tot ' $n$ sinvolle eenheid.

Die moderne mens is egter nie sondermeer bereid om sy lewe te laat bepaal deur' $n$ mag buite homself nie. Die denke van die tipiese moderne mens word gekenmerk deur sekularisasie en horisontalisme. ${ }^{1}$ Sekularisasie beteken verwêreldliking. Aanvanklik is met hierdie woord die proses bedoel waartydens kerklike goedere aan iemand oorhandig is met die oog op nie-kerklike gebruik. Later het dit die onttrekking van die kerk se gesag aan alle staatkundige en maatskaplike belange aangedui. In positiewe sin is die sekularisasie nog later beskou as die proses waarmee die mens bevry word van demoniese magte en ou bindende lewenspatrone. ${ }^{2}$ Heyns omskryf sekularisasie as "die veelsydige historiese proses waarin die mens bewus geword het van die belangrikheid van hierdie wêreld, sy roeping en taak in hierdie wêreld opnuut ontdek het, en die insig verwerf het dat die kerk en die teologie nie oor al die lewensterreine mag heers nie, en hy dus met sy selfstandige ondersoek van hierdie wêreld moet en kan voortgaan. ${ }^{\prime 3}$ In noue ooreenstemming met 
Heyns se Newbegin: "Secularization sets man free to question, to experiment and to make independent decisions. ${ }^{4} \mathrm{Op}$ die positiewe wat die sekularisasieproses vir kerk en teologie inhou, wil ons nie nou ingaan nie. Die negatiewe speel egter die oorheersende rol. Die langdurige sekularisasieproses het gelei tot 'n funksieverlies van godsdiens, kerk en teologie. Naas die kerk en die godsdiens het feitlik 'n nuwe selfstandige wêreld ontstaan van mense wat hulle aan niks meer bind nie. Van Wyk sê: "Die moderne mens weier om sy verstand en gewete, sy ervaring en kennis van sake uit te skakel om hom klakloos en onvoorwaardelik te onderwerp aan watter gesag op watter gebied ookal ... Die persentasie gelowiges wat sonder om self te dink, dinge glo net omdat dit in die Bybel staan, of omdat die kerk so leer of die predikant so sê, of omdat hulle ouers hulle so geleer het, word by die dag kleiner." 5 Die mens se hele lewe word horisontalisties van aard. Al wat geld is die hièr en nòu. Die relatiwisme word verheerlik. Standpunte word ingeneem volgens die eis van die situasie.

Midde in hierdie sekularisasieproses het die hedendaagse teologie gegroei en gebloei. Verskillende teoloë het die hedendaagse teologie met verskillende benamings beskryf o a anti-metafiese teologie, vernuwingsteologie, radikale teologie, horisontalistiese teologie, sekularistiese teologie, God-is-doodteologie en eksistensieteologie. Dit lyk of die benaming eksistensieteologie miskien die beste benaming is, want die hele hedendaagse teologiese denke word oorheers deur die eksistensie van die mens. Die mens in sy huidige eksistensie is die vertrekpunt, die eindpunt en die middelstuk van hierdie teologiese denke. Met Bultmann aan die spits het 'n groot groep teoloë gevolg wat dieselfde pad geloop het so o a Paul Tillich, Robinson, van Buren, Altizer, Hamilton, Winiter, Cox, Fuchs, Ebeling, Dorethee Sölle en ander. ${ }^{6}$ Elkeen van bg teoloë se denke kan nie volledig bespreek word nie en gevolglik gee ons eerder 'n dwarsdeursnit van enkele karakterestieke van die hedendaagse teologie in soverre dit van belang is vir die kategese.

\section{Die Bybel}

1.1 Verkondiging: Tot 1955 het Barth die teologiese toneel oorheers. ${ }^{7}$ Die oneindige verskil tussen openbaring en natuur, die leer aangaande die Heilige Skrif, Christus se middelaarskap en ander dogmatiese diskussies het in die middelpunt van die teologiese denke gestaan. ${ }^{8}$ Die era van Barth is afgesluit en opgevolg deur diè van Bultmann. Ander vrae het in die middelpunt van die teologiese diskussie te staan gekom. Een van die sentrale vrae is die vraag na die wyse waarop die moderne mens met die Bybel omgaan. Veral Tillich het besondere aandag aan hierdie saak 
gegee. ${ }^{9}$ Die teologie van vroeër beskryf hy as kerugmatiese en apologetiese teologie. Hierdie teologie sê hy vra net na die kerugma en na niks anders nie. Die Woord moet verkondig word en die mens opgeroep word tot die geloof. ${ }^{10}$ Tillich se beswaar teen hierdie teologie is dat dit hoegenaamd nie aandag gee aan die mens in sy konkrete situasie nie. Teenoor die kerugmatiese stel Tillich die apologetiese teologie." Dit is een wat heen en weer beweeg tussen God en mens, tussen die kerugma en die situasie, tussen die antwoord en die vraag." 11 Die mens van die twintigste eeu het 'n volkome ander wêreldbeeld as die mens uit die Bybel se tyd. Die mens van vandag en die mens van die Bybel se omstandighede verskil geheel en al. Die eksistensie teologie se oog en oor is in die eerste plek gerig op die mens van hier en nou. Hierdie teologie se ganse denke word bepaal deur dit wat voorhande is. Op grond van die moderne mens se opvattings oordeel Paul van Buren en J A T Robinson dat God en alles wat tot ' $n$ ander wêreld behoort uit die teologiese diskussie en die verkondiging uitgesluit moet word. ${ }^{12}$ Die katolieke teoloog Dewart het Paul van Buren en J A T Robinson met radikale denke vèr oortref. Waar Robinson en ander hoofsaaklik wil ontmitologiseer en onthelliniseer wil Dewart dat selfs die inhoud van die Bybel prysgegee moet word. Die Bybel sê hy is slegs bestem vir die situasie waarin dit geskrywe is en nie vir die hedendaagse situasie nie. ${ }^{13}$

1.2 Ontmitologisering: Die "vernieuwingteologie" het volgens $R$ Schippers met Bultmann se "ontmythologisering" begim. ${ }^{14}$ ' $n$ Mite is die wêreldse spreekwyse oor die bo- of onderwêreldse. Bultmann sê tereg dat die Bybel ontstaan het in 'n tyd toe 'n geheel ander voorstellingswêreld gegeld het. In die vorm van hierdie geheel en al ander verpakking het die Bybel tot ons gekom. Hierdie verpakking dra die stempel van sy tyd en het geen betekenis meer vir die latere geslagte nie. Hierdie mite of verpakking is nie deel van die geloof nie. Die kern is alleen die boodskap van die besondere gedeelte. Die mitiese kleed van die Bybel moet uitgetrek word en alleen die boodskap van die Bybel moet aan die mens voorgehou word, in die besonder alleen die boodskap vir die mens van hier en nou. Uit bogenoemde is dit duidelik dat Bultmann 'n geweldige invloed op die hermeneutiek uitgeoefen het. As sterk hermeutiese beginsel het nog altyd gegeld: Wat sê die perikoop, wat sê die teks. Vir Bultmann is dit nie die belangrikste nie. Vir hom is die belangrikste: wat sê die perikoop of die teks vir my as mens van hierdie tyd. Daar word met ander woorde eers gevra wat die moderne mens se nood is, voordat daar na die teks gekyk word.

Bultmann se ontmitologiserings proses het tot gevolg dat die 
pre-eksistensie van Christus, sy dood, opstanding en hemelvaart verwerp word. Dit het sogenaamd nie betekenis vir die mens van hier en nou nie.

Die moderne Bybeluitleg onderskei graag tussen werklikheid en waarheid. Met hierdie onderskeiding in die oog bewandel Käsemann feitlik dieselfde pad as Bultmann. In plaas van ontmitologisering praat hy liewer van dehistorisering van die Skrif. Hy maak skerp onderskeid tussen historie en geskiedenis. Historie is volgens hom verstarde geskiedenis. Elke gebeure sê hy bestaan uit historie en geskiedenis. By wyse van voorbeeld kan dit soos volg verduidelik word. Dawid se oorwinning oor Goliat is ' $n$ historiese gebeure. Die geskiedenis van die gebeure is: Hulle wat op die Here vertrou, vertrou nie tevergeefs nie. Die historie sê hy is verstarde gebeure, dit is niksseggends. Die enigste wat blywends is, is die geskiedenis die boodskap. Volgens Käsemann is die Bybel geskiedenis wat deur menslike historie versier is. Hierdie versiersel moet weggeneem word sodat net die boodskap oorbly. Om die Bybel te onthistoriseer sê hy is die histories-kritiese ondersoek met sy apparaat van tekskritiek, literêre kritiek en vormkritiek van die allergrootste belang.

Kuitert praat feitlik dieselfde taal as Käsemann. Volgens hom het die evangelieskrywers die Bybelse feite gewysig om by die besondere boodskap te pas. ${ }^{15}$

\section{God en die wêreld}

Volgens die moderne teoloë moet die skeiding tussen subjek en objek in die teologie opgehef word. Die afstand tussen die "diesseits" en "jenseits" moet oorbrug word. Immanensie en transedensie moet een word. Daar is net een wêreld en dit is die wêreld van hier en nou. In hierdie wêreld is God betrokke en daarbuite nie. ${ }^{16}$ Die God wat in die hemel woon, bestaan nie. Hy is dood. Die oorgelewerde Godvoorstelling word ontken. Die God van die nuwe teologie het Hom aan die wêreld oorgegee. Hy kom na die wêreld in die gestalte van Jesus van Naseret. Hierdie hele opvatting maak die teologie tot 'n teologie wat alleen gerig is op die teenswoordige wêreld. Hier is die lewe, hier die verantwoordelikheid, hier die geluk. Wat nie hier is nie bestaan nie. Die kern van die teologiese diskussie is daarom nie sake soos God se drie-eenheid nie, maar sake wat die mens se bestaan ten nouste raak soos byvoorbeeld rassediskriminasie ensovoorts. In die plek van die dogmas van die verlede, word die funksionele van die oomblik gestel. 


\section{Jesus Christus}

Sedert die laaste 200 jaar werp liberale teoloë alles in die stryd om die historiese Jesus weg te redeneer. In Bultmann se rekonstruksie is daar nie 'n pre-eksistensie van Jesus nie, geen maagdelike geboorte, geen sondeloosheid en goddelike natuur nie, geen versoening, geen hemelvaart en wederkoms nie. Die bedoeling van die Bybel is volgens hom nie dat ons moet glo dat Jesus vir ons gekruisig is nie. Die bedoeling is dat ons onsself moet oorgee aan ons naaste volgens die weg van die kruis. So sê hy kry die mens deel aan die opstandingslewe. Jesus se opstanding beteken slegs vir die mens 'n nuwe verhouding tot medemens waarin Jesus se kruisiging vir jou die ewige voorbeeld is van jou opofferende houding met betrekking tot jou medemens.

Die eksistensie-teologie se opvattings in verband met Jesus Christus kom veral goed tot uitdrukking in Dorothe Sölle se beskouings. Sy beskryf Jesus as die voorlopige en die voorlopende. Die klem val op laasgenoemde. Christus loop voor ons as die volmaakte voorbeeld en $\mathrm{Hy}$ is voorlopig want Hy verteenwoordig God. Christus loop dus ook voor God uit. God self sê sy, is buite die wêreld. Christus is die plaasbekleder van God. Die enigste wat nou van die mens verwag word, is om die voorloper te volg. Hy tree egter terug as onsself kan aangaan. ${ }^{18}$ In hierdie verband beskryf sy Jesus as leermeester by uitnemendheid. 'n Leraar loop voor, maar verdwyn as die leerling selfstandig geword het. Waar die mens in die moderne tyd mondig geword het, het hy in werklikheid nie meer hierdie voorloper nodig nie. Jesus het vandag nog net betekenis in soverre as wat $\mathrm{Hy}$ die ewige voorbeeld van medemenslikheid is. Die werklike betekenis van die Evangelie is daarom: Bemin jou naaste, wees medemenslik. ${ }^{19}$

Treurnicht vra die vraag: "Wie is Christus vir die moderne eksistensieteoloë?" Nie 'n goddelike persoon met twee nature nie, maar die toppunt van menslike voortreflikheid. Van 'n plaas-bekledende lyding en sterwe, van versoening wil hulle niks weet nie. Christus is in sy lyding en sterwe slegs voorbeeld van offervaardigheid. ${ }^{20}$

\section{Die Mens}

4.1 Die mondigheid van die mens: Dorothe Sölle lê in hierdie verband besondere klem op die rede van die mens. Hierdie rede of verstand van die mens moet die wêreld deur middel van die wetenskap beheers. Ons is die seuns van God en die wêreld is ons erfdeel. Die mens met sy rede is outonoom, hy is mondig. Hy erken geen gesag bokant sy rede nie. Alleen daardie gedeeltes van die Bybel wat nie bots met jou verstand nie, is aanvaarbaar.

Die moderne mens bevind hom in 'n unieke situasie. Op weten- 
skaplike en tegnologiese vlak het daar 'n oneindige ontwikkeling plaasgevind. Afstande, grense en tye is oorbrug. Dit wat 30 jaar gelede vir die mens nog vreemde en selfs verbode terrein was, het nou deel geword van die alledaagse. So het die mens in die moderne tyd getoon dat nie alleen die aarde sy beweegruimte is nie, maar dat hy selfs die ruimtes kan binnedring. Dag vir dag gaan die mens verder om sy heerskappy oor die natuur te laat toeneem. Namate die tegnologiese wiele verder rol en groter terreine verower word, neem die mens se besef toe dat die verowerde gebied sy eie verantwoordelikheid is. Hierdie verantwoordelikheid word aangedui as die mens se mondigheid. Ditwat die mens nog 20 jaar gelede van God gebid het, beskou die moderne mens as sy eie verantwoordelikheid.

Dit was veral Bonhoeffer in sy "Widerstand und Ergebung" wat besondere aandag aan die mondigheid van die moderne mens gegee het. Die mondigheid van die moderne mens en sy religieloosheid loop hand aan hand. Bonhoeffer poneer dat met die voortskrydende mondigwording van die wêreld, God steeds meer en meer uit die wêreld weggedring word totdat Hy geheel oorbodig geword het. Hierdie proses om God uit die wêreld uit te druk is 'n proses wat reeds van die begin van die Paradys-dae aan die orde is. Die mens wil nie dat God vir hom sal voorskryf met betrekking tot die wêreld waarin hy leef nie - hy as mens wil dit self doen. Die hoogtepunt van hierdie uitdruk van God uit die wêreld vind plaas as die mens, die seun van God bokant die wêreld aan 'n kruishout hang.

4.2 Medemenslikheid: In die hedendaagse teologie word die leer oor die mens op die yoorgrond gestel. Die moderne situasie het die oog van die teoloog ge-open vir dit wat voorhande is. Die oneindige verskil tussen ryk en arm, wanverhoudings en diskrimminasie het penne en denke in beweging gebring. Die teologie het oog gekry vir die "diesseitige". Die prediking en die onderrig is nie meer gerig op die "hiernamaals" nie, maar die "hiernoumaals." ${ }^{21}$ Die belangstelling vir die hemel is verruil vir die belangstelling vir die aarde. Die vertikale teologie is vervang met 'n horisontale teologie. Op grond hiervan word gesê dat die kerk se enigste taak is: die bemoeienis met die mens in nood. Die ervaring van en met die transedente God is alleen moontlik in die medemens. Die kerk moet slegs dienskneg van God in die wêreld vir die wêreld wees. Robinson pleit baie sterk vir 'n "leketeologie". Dit is ' $n$ teologie wat begin by die vrae en die probleme van die mens en wat ook daar eindig. ${ }^{22}$ Reeds Emil Brunner het besondere klem gelê op die mens in nood. Volgens hom moet die mens eers bewus gemaak word van sy nood voordat hy ontvanklik is vir die Evangelie. ${ }^{23}$ 


\section{Die Kerk}

Met die beskrywing van die eksistensieteoloë se beskouings oor die mens, is reeds in breë trekke gesê wat hulle beskou as die kerk se taak en roeping in die wêreld. Dit was veral Bonhoeffer wat die beskuldigde vinger baie skerp na die kerk gewys het. Die kerk sê hy het vir baie jare slegs religie aan die wêreld verkondig en sy oë vir die nood van die wêreld gesluit. Vir die kerk sê hy behoort dit te gaan om die mens in sy konkrete situasie. Die kerk moet hom daarom in die eerste plek rig op die welvaart van die mens en nie op sy verlossing uit sonde en dood nie. Die nood waaruit die mens bevry moet word is sy politieke, sosiale en materiële nood. Op grond van hierdie beskouing sê Treurnicht het dit vir die hedendaagse kerk moontlik geword om God in die betoging te dien; want God word gevind in die nood van die mens. ${ }^{24}$

\section{Die Etiek}

Soos reeds gesê, val die klem in die moderne teologie nie op die hiernamaals nie, maar op die teenswoordige wêreld. Die tweede tafel van die wet word sentraal gestel en die bergprediking van Jesus is die sentrale tema van die verkondiging. Jesus word slegs beskryf as die sosiale hervormer wat die mens bevry van sosiale onreg. Die kruisiging van Jesus en Sy opstanding het feitlik geen betekenis nie. "The only certain path to heaven lies over the sometimes rugged but never impassable road of a good life." Die tweede tafel van die wet is hier die enigste wat nog 'n sê het. Oortreding van die eerste vier gebooie is nie iets om jou oor te bekommer nie.

Die moderne teologie se stelling dat God dood is, lei noodwendig daartoe dat gesê moet word dat God se gebooie ook dood is. Begrippe soos gehoorsaamheid aan God word beskryf as outyds en niepassend vir die moderne denke nie. Die enigste beginsel wat geld vir die moderne etiek is of jy jouself vir jou medemens gee of nie. Hierdie opvatting lei tot verrykende afleiding. Dit maak die deur oop dat jy feitlik alles kan doen met slegs die verskoning dat jy op een of ander wyse besig is om jouself vir jou medemens te gee. As jy met die sogenaamde moderne vryheidsbewegings saamwerk en jou geld gee vir terrroriste organisasies dan is jy op die regte pad - jy is besig om jou vir jou medemens te gee. “Om seksuele verkeer buite die huwelik te weier kan beteken dat mens jou nie gee nie!!"26

Robinson bestry wat hy noem die "Supra naturalistiese" moraal waarvolgens goed en kwaad vasgelê is in wette wat direk van die hemel sou kom. Daar is volgens hom geen van buite opgelegde norme nie. Die alleen bepalende vir hom is die oopwees vir die mens in sy situasie. 'n Bepaalde gebod word nie nagekom omdat God of 
Jesus of Paulus so sê nie, maar omdat die mens in sy konkrete situasie dit vra. Onder alle omstandighede moet die mens net luister na sy eie innerlike. "Indien die welsyn van die eggenote beter bedien kan word deur egskeiding, is weiering daartoe immoreel." ${ }^{27}$

Die vraag is nou watter invloed behoort die eksistensieteologie op die kategese te hê en wat behoort die kerk se reaksie in sy kategese te wees op die eksistensieteologie.

Om die oë vir die bestaan van die eksistensieteologie te sluit, sou niks minder as dwaas wees nie. Hoewel die kerk nie van die wêreld is nie, is die kerk tog in die wêreld. Die kerk se verkondiging is juis gerrig tot die mens in sy konkrete situasie in die wêreld. Deur die radio en die televisie, die tegnologie en die pen is die groot afstande van verskillende wêrelddele oorbrug. Dit sou daarom dwaas wees om te beweer dat die eksistensieteologie buitelandse teologie is wat nooit by ons sal uitkom nie. Volgens van $W y k,{ }^{28}$ hoewel nie in dieselfde terme nie, het hierdie teologie reeds by ons uitgekom. Is die gesindheid van die moderne mens, nie reeds hier by ons hoofsaaklik gerig op die hier en die nou nie? Met ander woorde al het die gewone mens in ons land nog nie woordeliks kennis geneem van die eksistensieteologie nie, het hy reeds begin leef as 'n wese vir wie al die beginsels van hierdie moderne teologie geld.

Om die eksistensieteologie sondermeer te beskryf as sinneloos en ons eie wyse van doen en verkondiging te beskryf as die enigste sinvolle, is niks anders as hoogheidswaan nie. Hoewel die negatiewe seker oorheersend is, het die eksistensieteologie seker ook sy positiewe kant. In verskeie opsigte het die eksistensieteologie met betrekking tot die kerk se verkondiging weer die kerk se oë oopgemaak. Waar die eksistensieteologie hom hoofsaaklik besig hou met die "teenswoordige wêreld", het die kerk in die verlede hom hoofsaaklik besig gehou met die "hemelse wêreld". Waar die horisontale dimensie vir die eksistensieteologie die een en die al is, was dit alleen die vertikale dimensie wat ter sprake was in die teologie van die verlede. Die eksistensieteologie het die kerk weer oog laat kry vir die teenswoordige wêreld. Dit het die kerk laat besef dat hy in sy verkondiging nie net aandag aan die vertikale dimensie moet gee nie, maar ook aan die horisontale dimensie.

Die positiewe invloed van die eksistensieteologie behoort deur te werk na al die verkondigingsgestaltes van die kerk. Met betrekking tot die kategese kan die volgende opmerkings gemaak word:

1. Die doel van die kategese is in die verlede breed omskryf. De Wet $^{29}$ sê die kategese beoog die stigting en die vermeerdering van die geloof van die katkisant. Vir van Uchelen ${ }^{30}$ is kategese heilige onderrig wat die jong lidmate van die kerk versorg met die oog op hulle toekomstige lewe in die gemeente. De $\mathrm{Groot}^{32}$ sê die kategese wil daartoe lei dat die katkisant uiteindelik in die wêreld sal 
gaan leef tot eer van God. Sy besondere verstaan van die kategese druk die Nederduitsch Hervormde Kerk van Afrika uit in sy Kerkwet en bepalings. "Die kategese het tot doel om die jeug van die Kerk en hulle wat tot die Kerk wil toetree te onderrig aangaande die leer van die Kerk en die betekenis van hulle dooplidmaatskap van die Kerk waarin hulle opgeneem is deur die doop, om hulle voor te berei vir die deelname aan die heilige sakramente en vir die aanvaarding van medeverantwoordelikheid vir die opbou van die Godsryk in die algemeen en van die Nederduitsch Hervormde Kerk van Afrika in die besonder". ${ }^{32}$

Op die oog af mag dit lyk of bogenoemde be-oefenaars van die Kategetiek, die kategese alleen wil be-oefen met die oog op die geloof in God wat daarbo is, en niks te doen het met die alledaagse lewe van die mens nie. By nadere ontleding blyk die teendeel waar te wees. Die probleem is egter dat dit nie altyd so verstaan is nie en gevolglik het die een dimensionele aspek in die kategese bly voortbestaan. As die Wet sê die kategese beoog die stigting en die vermeerdering van die geloof in Jesus Christus dan verstaan hy onder geloof, soos hy dit self noem, ortodokse geloof. Dit is geloof wat reg glo, maar wat ook reg leef - geloof en werke wat onlosmaaklik aan mekaar verbonde is. Van Uchelen se "toekomstige lewe in die gemeente" is 'n lewe van geloof en werke. De Groot se "tot eer van God" is juis geloof in die wêreld wat versier is met goeie werke. Die Nederduitsch Hervormde Kerk wil die katkisante onderrig in die leer van God. Hierdie leer is die leer soos dit vir ons opgeteken is in die Bybel en die belydenisgeskrifte. Hierdie leer is nie alleen heilsindikatief nie, maar ook heilsimperatief. Dit getuig nie alleen van die genade van God nie, Dit roep die mens ook op tot die geloof en die goeie werke. Die kerk wil juis dat die katkisant uiteindelik sal meewerk tot die bloei van die Godsryk in die algemeen en van die Nederduitsch Hervormde Kerk in die besonder. Dit wil juis dat die katkisant sy geloof in die wêreld sal gaan uitleef. Die Kerkwet sê die kategese lei van die doop na die nagmaal. Kategese wat reg bedien word, vind juis rondom hierdie punt 'n besondere "aanknopingspunt" om die indikatief en die imperatief van die Woord duidelik te laat spreek. Die doop getuig van die genade van God; maar tegelyk word ouer en kind op grond van die genade wat aan hulle toegesê is, opgeroep om in die wêreld te leef soos mense aan wie die verbond van God betuig en verseël is. Met die nagmaal wil God die swak en wankelende geloof van die mens voortdurend versterk, sodat hy standvastig in die geloof in die wêreld sy geloof sal uitleef.

In die verlede het die kerk in sy kategetiese arbeid die klem miskien te veel op die leer en te min op die lewe laat val. Tot vandag 
toe word gepraat van geloof en goeie werke. Dogmaties gesien is dit seker korrek. As die Bybel egter sê dat geloof sonder werke dood is en ons sou hierdie stelling wiskundig neerpen dan moet ons sê dat geloof sonder werke is nul, dit bestaan nie. Van hieruit gesien moet ons dan liewer net praat van geloof en dan word daarmee geloof bedoel waarvan die goeie werke' $n$ wesenlike deel is. Dit is die taak van die kategeet om die "geloof" so uit te lê dat die katikisant sal besef dat die feit dat hy glo noodwendig ' $n$ bepaalde lewe van gehoorsaamheid en diens aan God meebring. Die geloof moet gestalte aanneem in die lewe van die katkisant hier en nou. Elke geloofsvraag moet deurgetrek word tot in die praktyk. Hierdie metode van behandeling bied nie alleen troos in sterwe nie, maar ook in lewe. Dit vra nie alleen dat die katkisant die indikatief sal ken nie, maar ook die imperatief. Dit roep die katkisant nie alleen op tot liefde vir God nie, maar ook liefde vir die medemens.

2. Die positiewe element in die eksistensieteologie moet egter nie daartoe lei dat die oog gesluit word vir die negatiewe nie. Dit is die taak van die kerk om vir sy katkisante die ieuen aan die lig te bring en teenoor die leuen die waarheid te stel. Dit is seker nie nodig om tydens die kategese 'n aparte hoofstuk, wat handel oor die eksistensieteologie, in te voer nie. Die breë lyne, soos tans die geval in die Nederduitsch Hervormde Kerk is, kan behandel word wanneer die twintigste eeu se teologie ter sprake kom. ${ }^{33}$ Die fyner besonderhede, en dan in die besonder die negatiewe afwysing, kan plaasvind terwyl die bestaande geloofsleer vrae behandel word. Hiermee bedoel ons dat wanneer die kategeet byvoorbeeld handel oor die kerk, hy dan in sy behandeling ook die opvatting van die eksistensieteologie ter sprake sal bring en vanuit die bestaande antwoord vir die katkisante sal toon waar die eksistensieteologie die pad byster geraak het.

3. Met die oog op meer volledigheid en ter wille van die waarheid wil ons net kortliks teenoor die opvattings van die eksistensieteologie soos reeds uiteengesit, die waarheid stel soos die Bybel dit aan ons verkondig soos die kerk dit deur die eeue verstaan het.

3.1 Vir die eksistensieteologie het die Bybel alleen betekenis in soverre dit 'n boodskap bied vir die mens van hier en nou. Hierdie kern-opvatting van hulle in verband met die Bybel maak ontmitologisering en dehistorisering van die Bybel sondermeer tot ' $n$ moontlikheid. Die feitlike situasie is egter dat die Bybel self verkondig dat dit as geheel gehandhaaf wil word ${ }^{34}$ Die Bybel bied self, as ons dit so mag stel, die hermeneutiese beginsel, dat die kerk altyd moet sê: "So sê die Here. ${ }^{\prime 35}$ Die primêre vraag vir die kerk is daarom nie: wat is 
die behoefte van die moderne mens nie, maar wat sê die Here, wat sê die Woord. Die vertrekpunt is die Bybel en nie die mens nie. Die Bybel moet die mens aanspreek in sy konkrete situasie en nie die mens in sy konkrete situasie moet die Bybel aanspreek nie.

3.2 Die hele teologie van die eksistensieteologie is gerig op die hier en die nou. Hulle sê: wat nie hier is nie bestaan nie. Hierdie opvatting het noodwendig daartoe gelei dat alle vrae in die teologie wat handel oor die wese van God, van die tafel afgegooi is. Anders as wat die eksistensieteologie beweer, is dit juis die "ken" van God wat in die Bybel voorop staan. Die Bybel is nie in die eerste plek openbaring van die mens nie, maar openbaring van God aan of vir die mens. Waar die eksistensieteologie alles verskuif na die hier en die nou, neem die hier en die nou in die Bybel altyd die sekondêre plek in ${ }^{36}$

3.3 Die waarheid van die Bybel is nie ' $n$ waarheid wat as waar bewys moet word nie, maar wat sondermeer geglo moet word. Dit bring noodwendig mee dat dit nie op die weg van die teologie lê om die historisiteit van Jesus te bewys nie, maar om dit sondermeer te aanvaar as die waarheid. Uit die Bybel self is daar geen gronde om die pre-eksistensie van Christus, sy maagdelike geboorte, sy hemelvaart, opstanding en wederkoms te ontmitologiseer soos die eksistensieteologie doen nie. Die weglating van hierdie kerngebeure uit die Christologie is niks anders as ' $n$ aantassing van die openbaring van God nie. Die poging om op hierdie wyse die godheid van Christus te negeer, is tipies van hierdie teologie wat alles wil laat afspeel op die vlak van die mens. Christus is veel meer as net voorloper van en voorbeeld virdie mens. Jesus Christus is die Seun van God. Hy is God self. ${ }^{37} \mathrm{Hy}$ is die verlosser uit sonde en dood ${ }^{38} \mathrm{Hy}$ is slegs voorloper in soverre Hy die een is wat eersteling uit die dood ${ }^{39}$ en eersteling in die hemel is.

3.4 As Jesus Christus opvaar na die hemel beteken nie dat die wêreld nou sonder God is en die mens nou mondige heerser van die wêreld word nie. Jesus Christus se weggaan uit die wêreld na die vlees beteken juis die inkom van God in die wêreld in die gestalte van ' $n$ omvattende wyse, in die gestalte van die Gees. ${ }^{40}$ Hoewel Christus die mens bevry van sonde en dood bly die mens nog van nature slaaf van die sonde en die dood. Die verganklikheid en beperktheid van die mens word nie opgehef nie. Die mens word nie mondig nie, maar bly steeds die afhanklike. Tot in lengte van dae geld die Woord: As die Here die huis nie bou nie, tevergeefs werk die wat daaraan bou. ${ }^{41}$ Christus se verlossing beteken nie die troon bestyging van die mens se verstand nie, maar juis die onttro- 
ning daarvan. Die geloof in Hom verhef die mens nie tot ' $n$ wese wat tot alles in staat is nie, maar moet juis die besef die geloof meebring dat God alleen alles kan doen (as dit ooreenstem met sy wil)..

3.5 Die eksistensieteologie het die moderne mens met sy medemenslikheid in die middelpunt van alles geplaas. Die weg van die teologie is die omgekeerde van wat die eksistensieteologie voorstel. Omdat die teologie nie antropologie is nie, is sy vertrekpunt God en nie die mens nie, die Bybel en nie die eksisterende mens van hier en nou nie. Omdat die eer van God en nie die verheerliking van die mens voorop staan nie, is die teologie dienskneg van God vir God in die wêreld. Die liefde tot die medemens sal altyd 'n plek moet hê in die teologie. Dit is egter nie die horisontale dimensie wat voorop moet staan nie, maar die vertikale dimensie. Die liefde tot God kom altyd eerste. ${ }^{42}$ Eers as die mens God liefhet kan hy sy medemens liefhê. Die mens se liefde vir God en sy medemens is alleen moontlik omdat God die mens eerste liefgehad het in Jesus Christus. Omdat God, die verlossing in Jesus Christus, die ewige brood, die belangrikste is, is die mens se grootste verantwoordelikheid teenoor sy medemens nie die bevryding uit materiële nood nie, maar die bevryding van sy geestelike nood. Hierdie bevryding is alleen moontlik deur Jesus Christus. Dit bring mee dat die mens se eerste taak teenoor sy medemens die verkondiging van die evangelie van Jesus Christus is. Hierdie opdrag plaas Jesus Christus ook eerste as Hy sy kerk die wêreld instuur. ${ }^{43}$ Die kerk se taak is nie in die eerste plek om die mens te bevry van alle sosiale nood nie, maar om die evangelie van Christus aan die mens iń sy sosiale nood te verkondig. Eers in die tweede plek is dit die taak van die kerk om brood aan die hongeriges te gee.

3.6 Jesus Christus het nie gekom om die gebooie van God te ontbind nie, maar om dit te vervul. Sy gebod van liefde is in die eerste plek gerig tot God en eers in die tweede plek tot die mens. Liefde vir God en liefde vir die mens moet in hulle samehangende verband gehandhaaf word. Die onderhouding van God se gebooie het nie sy grond in die eksistensie van die medemens nie, maar in die opdrag, die openbaring van God. Die vraag wat voorop staan is nie: wat is my begeerte en wat is die verlange van my medemens nie, maar wat beveel God.

1. J H van Wyk, Eksistensieteologie en Godsdiensonderrig, Pro Rege-Pers Beperk, Potchefstroom 1971, bl 9. 
2. F J van $\mathrm{Zyl}$, die reformatoriese verkondiging en die hedendaagse mensbeskouing, Hervormde Teologiese Studies, 13(3), bl 120.

3. J A Heyns, Sekularistiese Teologie, Bulletin van die SAVCW, no 18, April 1969 , bl 2.

4. L Newbigin, Honest religion for secular man, SCM Press, London, 1963, bl 69.

5. J $\mathrm{H}$ van Wyk, aw, bl 16.

6. J Sperna Weiland, Orientatie nieuwe wegen in de theologie, Wereldvenster Baarn, 1966, gee 'n eenvoudige duidelike beskrywing van die meeste van hierdie teoloë se opvattings.

7. A Dekker en G Puchinger, De oude Barth, J H Kok N V Kampen, 1969.

8. Sien in hierdie verband veral Karl Barth, Kirchliche Dogmatik verskillende bande en G C v Niftrik, Kleine Dogmatiek, Nijkerk.

9. J Sperna Weiland, a.w., bl 49.

10. P. Tillich, Systematic Theology, Volume 111, deel IV, London, 1957, bl 7.

11. J H van Wyk, a w, bl 123.

12. $\mathrm{F} \mathrm{J}$ van $\mathrm{Zyl}, \mathrm{a} \mathrm{w}$, bl $\mathbf{1 1 5}$

13. J $\mathrm{H}$ van Wyk, a w, bl 125 en 126

14. R Schippers, Rudolf Bultmann en de ontmythologisering, in G Berkhouwer en A S van der Woude, Revolte in de Theologie, Een bundel beschouwingen over de zogenaamde vernieuwingsteologie, G F Callenbach N V Nijkerk, 1968, bl 157.

15. H M Kuitert, Verstaat gij wat gij leest? Over de uitleg van de bijbel, Kampen, 1969, bl 9-11.

16. GC v Niftrik, Theologische Revolte, in Berkhouwer en AS van der Woude, a w, bl 19.

17. J A Heyns, a w bl 32.

18. J H van Wyk, a w bl 178.

19. J A Heyns, a w bl 71-74.

20. A P Treurnicht, Godsdiens sonder God, Hoofstad, 17 Augustus 1978, bl 4.

21. J H van Wyk, a w bl 130.

22. J S Weiland, De Angelsaksiese vernieuwingsteologie, in Berkhouwer en A S van der Woude, a w, bl 55.

23. F J van Zyl, a w, bl 121.

24. A P Treurnicht, a w, bl 4.

25. L J Trose, Soos aangehaal J H van Wyk, a w, bl 185.

26. J $\mathrm{H}$ van $W y k, a \mathrm{w}, \mathrm{bl} 186$.

27. J C de Lange, Geskiedenis van die prediking in S.A., Hervormde Teologiese Studies, 23(3), bl 97.

28. J H van Wyk, a.w., bl 193.

29. J I de Wet, diktaatlesings 1964 , ongepubliseerd.

30. A C van Uchelen, Het Heilig Onderricht der Kerk, Holland Amsterdam, 1945.

31. G C de Groot, Hoe om ons Sondagskooluurtjie interessant te maak, uitgewer onbekend, 1950.

32. Kerkwet van die Nederduitsch Hervormde Kerk van Afrika, met wysigings soos aangeneem tot en met die 58ste Algemene Kerkvergadering, Bepaling 90:1, bl 60.

33. Vergelyk A D Pont, 'n Oorsig van die Algemene Kerkgeskiedenis en die Geskiedenis van die Nederduitsch Hervormde Kerk van Afrika, Tweede gewysigde en verbeterde uitgawe, H.A.U.M. Pretoria, bl 163.

34. Handelinge 20:27, 2 Timoteus 3:16 en Openbaring 22;19.

35 . Vergelyk veral die profete se toesprake.

36. Matteus 6:33.

37. Nederlandse Geloofsbelydenis, artikel 11.

38. Nederlandse Geloofsbelydenis, artikel 21.

39. 1 Korintiërs 15:23.

40. Johannes 14-16.

41. Psalm 127:1

42. Matteus 22:34-40.

43. Matteus 28:19 en Handelinge 1:8. 